\title{
Substructure and orientation heterogeneity of polycrystalline aluminum and its changes during plastic deformation
}

\author{
E.E.Badiyan, A.G.Tonkopryad, O.V.Shekhovtsov, \\ R.V.Shurinov, T.R.Zetova \\ V.Karazin Kharkiv National University,
Svobody Sq. 4, 61022 Kharkiv, Ukraine
}

Received November 28, 2016

\begin{abstract}
The results of experimental studies of the regularities of subgrain structure changing during plastic deformation of large-grained aluminum specimens with a parquet structure are presented. For most of the grains it is shown that the main substructure change has been the fragmentation of the subgrain structure, which is accompanied by an increase in the spectral width of misorientations. The effect of a dispersal of grain boundaries has been found and the mechanism of such dispersal is defined. The mechanism of the rotation of individual grains during deformation of the specimen and the subgrain structure role in such rotation are investigated. It is shown in experiment that specific and consistent restructuring of the subgrain structure took place in the individual grains during deformation of the specimen. It led to a change in crystallographic orientation of the grain, on the one hand, and to the relative deformation of the grain, which was significantly higher than the relative deformation of the entire specimen, on the other hand. Fine block structure with a wide spectrum of misorientations which changed during deformation of the grain was found near the boundaries of such grains. The presence of such a structure near grain boundaries played an accommodative role and excluded the possibility of discontinuities in grain and grain boundaries during deformation of the specimen.
\end{abstract}

Keywords: plastic deformation, spectrum of misorientations, subgrains, grain boundary.

Приведены результаты экспериментальных исследований закономерностей изменения субзеренной структуры в процессе пластического деформирования крупнокристаллических образцов алюминия с паркетной структурой. Для большей части зерен показано, что основными субструктурными изменениями является фрагментация субзеренной структуры, сопровождаемая увеличением ширины спектра разориентаций. Обнаружен әффект рассыпания границ зерен и определен механизм этого рассыпания. Исследованы и определены механизм разворота в процессе деформирования образца отдельных зерен и роль в этом развороте субзеренной структуры. Экспериментально показано, что в процессе деформации образца в отдельных зернах происходит специфическая и последовательная перестройка субзеренной структуры, приводящая, с одной стороны, к изменению кристаллографической ориентации зерна, с другой стороны, к относительной деформации зерна, значительно превышающей относительную деформацию всего образца. Вблизи границ таких зерен обнаруживается мелкоблочная структура с широким спектром разориентаций, который меняется в процессе деформирования зерна. Наличие такой структуры вблизи границ зерен играет аккомодационную роль и исключает возможность нарушения сплошности в области зерна и границ при деформировании образца. 
Субструктурна та оріснтаційна неоднорідність полікристалічних зразків алюмінію та їі змінення у процесі пластичної деформації. Є.Ю.Бадіян, А.Г.Тонкопряд, О.В.Ше ховцов, Р.В.ІІурінов, Т.Р.Зєтова.

Наведено результати експериментальних досліджень закономірностей змінення субзеренної структури у процесі пластичної деформації великокристалічних зразків алюмінію з паркетною структурою. Для більшої частки зерен показано, що основними субструктурними змінами є фрагментація субзеренної структури, що супроводжується збільшенням ширини спектра розорієнтацій. Виявлено ефект розсипання меж зерен i визначено механізм цього розсипання. Досліджено і визначено механізм розвороту у процесі деформації зразка окремих зерен, роль у цьому розвороті субзеренної структури. Експериментально показано, що у процесі деформації зразка в окремих зернах відбувається специфічна і послідовна перебудова субзеренної структури, що приводить, з одного боку, до зміни кристалографічної орієнтації зерна, з іншого боку, до відносної деформації зерна, що значно перевищує відносну деформацію усього зразка. Поблизу меж таких зерен виявляється структура із блоків маленького розміру з широким спектром розорієнтацій, який змінюється у процесі деформації зерна. Наявність такої структури поблизу меж зерен відіграє акомодаційну роль і унеможливлює порушення цілісності в області зерна та меж зерен під час деформації зразка.

\section{Introduction}

The regularities of the plastic deformation development of polycrystals and their mechanical properties are determined by the characteristics of the specimen structure. They include the average grain size, grain size distribution, grain shape and crystallographic orientation, the type of the grain boundaries and characteristics of the substructure and orientation heterogeneity within each of the grains. In connection with such a lot of the specimen characteristics before deformation it is impossible to predict a priori the regularities of the plastic deformation development in the specimens and ultimately mechanical characteristics. The above complicated by the fact that the mechanical properties of polycrystalline specimens depend not only on the original structure and substructure of specimens but also on the regularities of its self-consistent change during deformation of the specimen. Thus, to determine the relationship between changes in the structural characteristics of the specimen on the one hand, and the regularities of plastic deformation, on the other hand, it is necessary to determine the structure, substructure and orientation changes occurring during deformation of the specimen at the same time for all areas of its surface.

\section{Experimental}

For research used the method [1-3] obtaining color orientation maps. The technique is based on discovered by the authors the effect of diffraction of white light by quasi-periodic etching relief of the surface of a crystalline materials. It is shown in experiment that the characteristics of this quasi-periodic structure of a certain region of the specimen surface depends on its crystallographic orientation. Angular resolution techniques using method of visualization [4-6] achieves linear resolution in the determination of the dimensions of subgrains $1 \mu \mathrm{m}$ and angular $5^{\prime \prime}$.

Fig. 1 gives an example of the color orientation map of the surface of one of the grains of the polycrystalline aluminum

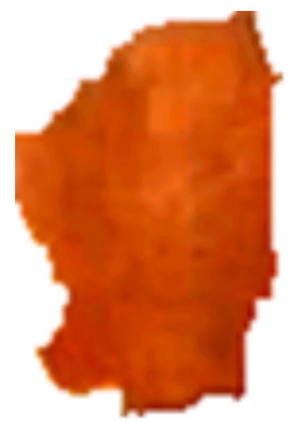

Fig. 1. Color orientation map of the surface of one of the grains of an Al polycrystal in hues of red color.

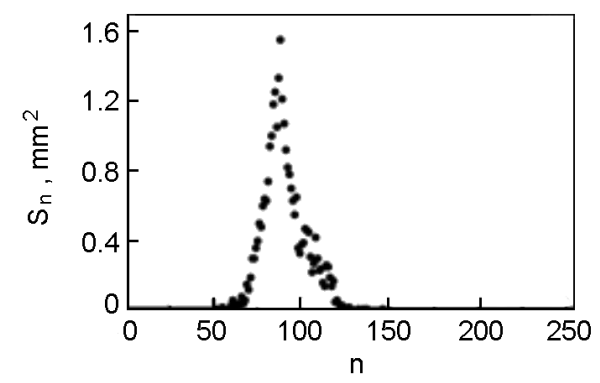

Fig. 2. Size distribution $\left(S_{n}\right)$ and conditional crystallographic orientation distribution $(n)$ of the grain surface fragments with a different orientation. 


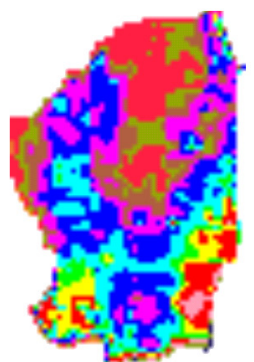

a)

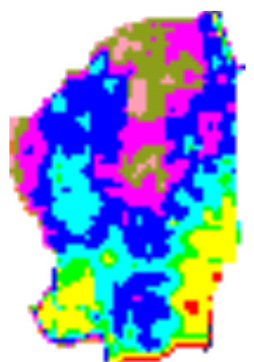

b)

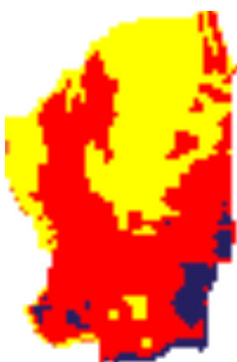

c)

Fig. 3. Color image of the surface of the grain which is shown in Fig. 1 after visualization of substructure and orientation heterogeneity with different angular resolution $\Delta n(\mathrm{a}-\Delta n=5 ; \mathrm{b}-$ $\Delta n=10 ; \mathrm{c}-\Delta n=20$ ).

specimen obtained in hues of red. COM demonstrates, at first glance, a substructure and orientation uniformity of the test grains.

Using method of visualization of the color image of the surface grain illustrated in Fig. 1, shows that the surface of the investigated grain substructure and orientation is heterogeneous (Fig. 2).

Visualization of this heterogeneity on the grain surface according to Fig. 2 may be performed by the replacement is visually indistinguishable hues of color visually distinct from pre-selected color space RGB [68]. The main criterion of visualization subgrain structure is the value of $\Delta n$, characterized by minimal misorientation neighboring subgrains. In Fig. 3 in an example of the visualization substructures of heterogeneity on the surface of the grain, shown in Fig. 1, depending on $\delta n$.

From Fig. 3 it can be seen that a decrease of the $\Delta n$, the number of subgrains identified at the grain surface increases. Thus, by changing the value of $\Delta n$ it is possible to increased or decreased (if necessary) an angular resolution of method to identify subgrain structure on the grain surface.

As objects of study used two-dimensional large-grained Al polycrystals, contains only continuous grain boundaries (the parquet structure). To obtain the specimens used fine-grained foil ( $\bar{a} \approx 0.1 \mathrm{~mm}$ ) of the aluminum purity of $99.96 \%$. The thickness of the foil, and all received from her specimens was $0.150 \mathrm{~mm}$, and working part $100 \times 20 \mathrm{~mm}^{2}$. The average grain size in the specimens $(10-20 \mathrm{~mm})$ was achieved by selection of the conditions of recrystallization (the magnitude of pre-strain of $2-3 \%$ and a temperature of recrystallization annealing). All specimens were thoroughly ground and polished. For color orientation maps on the surface of specimens of chemical etching method was created quasi relief. Quasiperiodic surface topography on a specimen created by chemical etching for 5-10 sec using a known etchant Keller's [7]. For each of the grains of the polycrystalline specimen before and after the destruction of deformation defined crystallographic orientation with respect to the stretching axis and the normal to the specimen surface. For all the grain boundaries held them full certification. All specimens were deformed in the conditions of active uniaxial tension at a constant rate of $5 \cdot 10^{-5} \mathrm{~s}^{-1}$ while automatically recording the deformation curve in the coordinates $\sigma=\sigma(\varepsilon)$. Color orientation maps during deformation of the specimen were detected using WEB-cameras Logitech C 920 HD Pro Webcam with a period $\approx 0.01$ sec.

\section{Results and discussions}

3.1 Substructural changes at an initial stage of plastic deformation

Using the method for producing the color orientation maps of the surface of the specimen and visualization to determine the substructure inhomogeneity on the surface of various grain polycrystalline possible to determine the state of stress relaxation mechanisms occurring in polycrystalline aluminum specimens in the early stages of plastic deformation.

So, during the deformation of almost all the specimens by a value not exceeding $\approx 0.1 \%$, observed effect substructure changes as a way to relax the stress state of the specimen during its alignment.

Fig. 4 shows an exemplary color orientation maps obtained from the surface of a polycrystalline aluminum grain specimen during deformation of the specimen to 


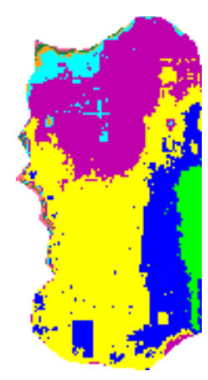

a)

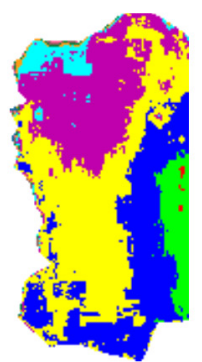

b)

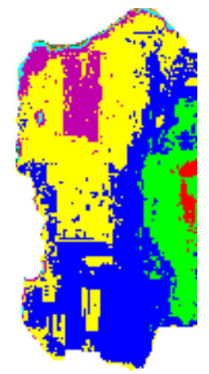

c)

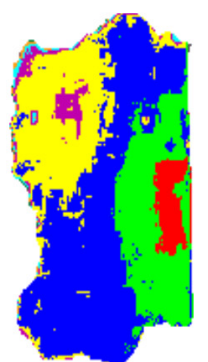

d)

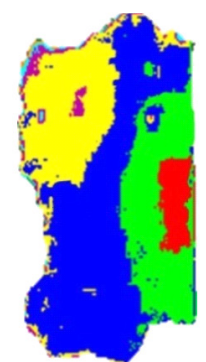

e)

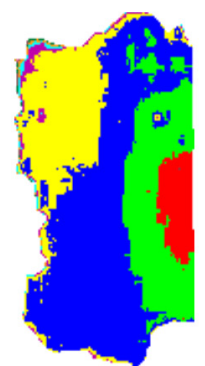

f)

Fig. 4. Changing substructure and orientation heterogeneity of one of the grains of an Al polycrystal during its deformation by: $a-\varepsilon=0 \% ; b-\varepsilon=0.04 \% ; c-\varepsilon=0.08 \% ; d-\varepsilon=0.1 \%$; e $-\varepsilon=0.2 \%$; $f-\varepsilon=0.6 \%$.
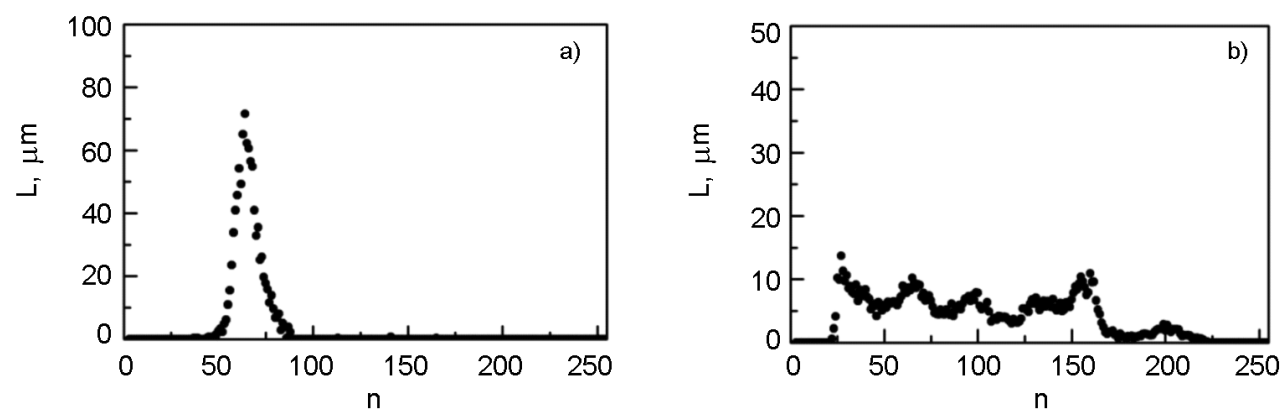

Fig. 5. Subgrain size distribution and conditional crystallographic orientation distribution of subgrains for one of the grains of an Al polycrystal: a - before deformation of the specimen; $b$ - after deformation by $17 \%$.

$0.6 \%$ after visualization a color image on them heterogeneity that characterizes inhomogeneity of the orientation and substructural grains. From these cards, clearly it is visible that the orientation changes happening in grain at the deformation which is not exceeding $0.1 \%$ in character in essence differ from the orientation changes taking place at deformation $\varepsilon>0.1 \%$.

COMs received from the surface of grain at $\varepsilon=0.04 \%-0.1 \%$, and their visualization show that in the course of deformation the sizes of areas of a surface of specimen with the same orientation change, however qualitatively distribution of color on the image of a surface of grain remains invariable. At deformation $\varepsilon>0.1 \%$ there is not only a change of the sizes of areas of a surface of grain to particular orientation, but also emergence of areas of a surface to new crystallographic orientation. The size of a critical strain $\varepsilon_{c r}$, corresponding to the end of process of alignment of specimen, depending on the studied specimen and grain in it changes ranging from 0.1 to $0.2 \%$.

When reaching the strain $\varepsilon \approx 5 \%$ occurs subgrain orientation and restructuring of the specimen of grain that is quite diverse in nature. Finally, substructural and orientation changes can lead to hardening of specimen, emergence on a straining curve of jumps of deforming tension, to increase in a local plastic strain of grain, fragmentation, emergence and crack propagation, etc.

\subsection{Fragmentation of structure}

The fragmentation of structures in individual grains during plastic deformation of a polycrystalline specimen of $\mathrm{Al}$ appears more often. This is due to inhomogeneity of the flow of plastic deformation of individual grains because of her constraint not only for the shear, and rotary mode of plastic deformation occurring at the expense of the environment grains adjacent grains.

Fig. 5 shows the results of research substructure changes taking place in one of the grains of polycrystalline aluminum specimen after deformation by $17 \%$. In the grain before deformation of the specimen is detected a microstructure with a narrow spectrum of conditional misorientations $\Delta n$ $=20$ (Fig. 5a). The average size of subgrains $\approx 40 \mu \mathrm{m}$. Deformation of the specimen at $17 \%$ leads to fragmentation sub- 


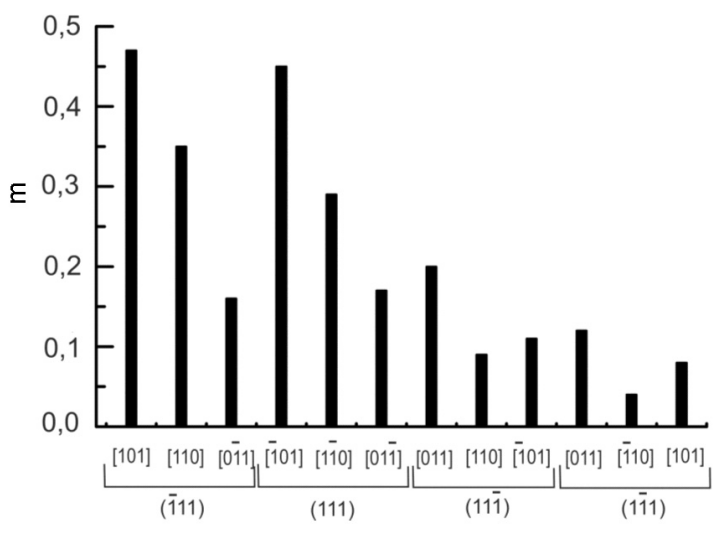

Fig. 6. Schmid factor distribution for all slip systems.

grain structure (Fig. 5b). The average subgrain size decreases to $\approx 5 \mu \mathrm{m}$ and misorientations range increases by 10 times. The presence of such a substructure in grain leads to asterism Laue spots on radiographs.

For an explanation of the possible causes of fragmentation of substructure were defined crystallographic orientation of grain in relation to an axis of tension and values of a factor Schmid for all systems of sliding (Fig. 6). Crystallographic orientation of an axis of tension of the aluminum specimen was the close to the side of main crystallographic triangle "[100]-[111]".

Follows from Fig. 6 that the system of sliding (111) [101] is the most loaded. The size of a factor Schmid for this system of sliding makes 0.47. Schmid factor for the conjugate system (111) [ $\overline{1} 01]$ hardly differs from the primary system. This provides a fast connection to the primary system, the secondary slip (conjugate). At such geometry of sliding in grain in it appears fragmented structure.
3.3 Influence changes of substructure accompanying the plastic deformation of polycrystalline specimen, to the shape of the deformation curve

It is well known that the most studied of the active modes of loading is uniaxial tension. The regularity of deformation in this method of loading has been well studied, and on polycrystalline and single-crystal specimens. In [8] presents an overview of modern ideas about the staging (the form) of the deformation curve and influence of substructure changes on the shape of deformation curves. In [9] is securely installed four-stage deformation curve for single crystals with the stretching axis oriented close to [001], and polycrystalline specimen in a wide range of grain sizes. In [10] considers various causes that lead to a change in the form of the deformation curve. In particular, its draw attention to the change in the number of active slip systems, incorporating rotational modes of plastic deformation and substructural changes accompanying the plastic deformation of the specimen.

The paper was examined over 20 specimen of aluminum with large grained size of 10-15 mm. All deformation curves have a parabolic shape. The reason for this can be the specificity of specimen for research. All specimens are two-dimensional polycrystals containing only through the grain boundaries. Experimentally shown that these specimens due to the absence of constraint in a direction perpendicular to the specimen surface, rotational changes become significant. The large grained $\mathrm{Al}$ specimen $(\bar{a}>10 \mathrm{~mm})$ using methods developed by investigations orientation and rotation changes in situ during the deformation of the specimen managed to detect the deformation stress
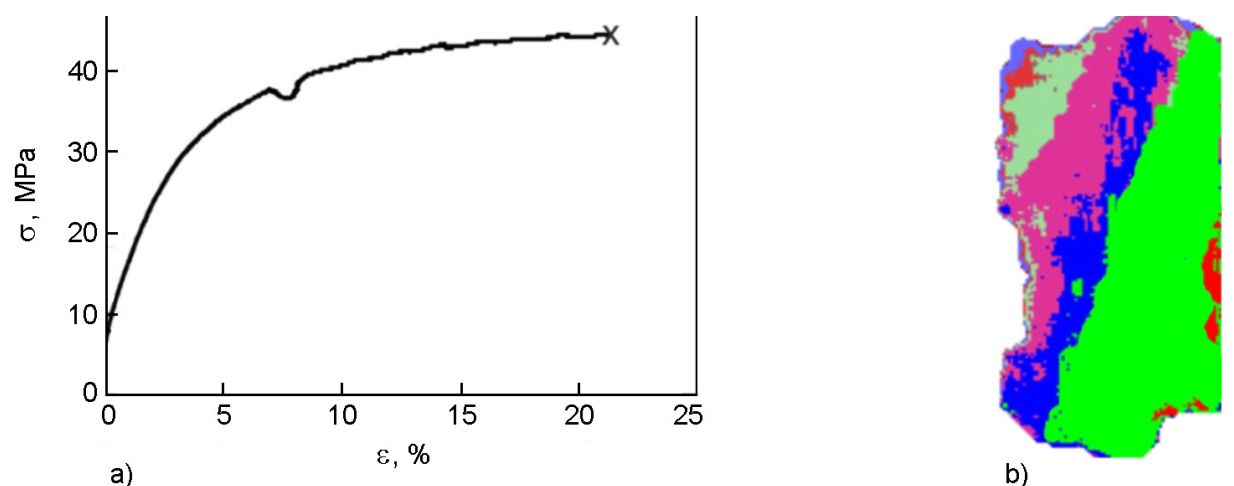

Fig. 7. A typical deformation curve of a large-grained Al specimen revealing a jump in the flow stress (a) and the color orientation map of one of the grains of an Al polycrystal after visualization (b). 


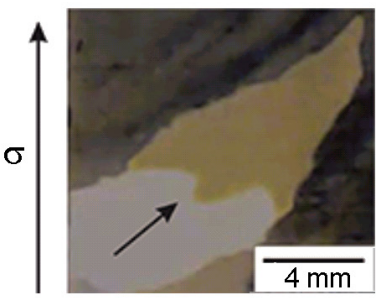

a)

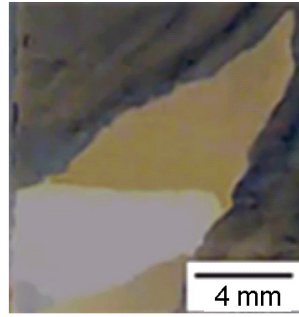

b)

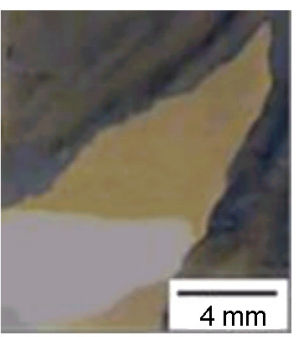

c)

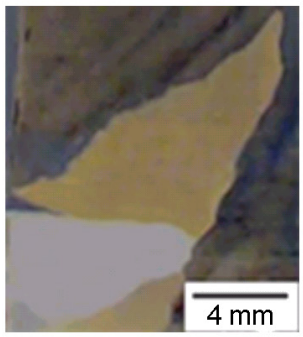

d)

Fig. 8. Color orientation maps of an Al polycrystalline fragment before deformation (a) and after deformation by $9 \%$ (b), $10 \%$ (c) and $11 \%$ (d).

surges. It is shown that the cause of such jumps is the emergence and rapid development of the reorientation region, crossing the whole grain.

On Fig. 7 shows a typical deformation curve (a) of $\mathrm{Al}$ polycrystalline specimen, revealing a jump in the value of the flow stress at strain $\approx 7 \%$ and the corresponding deformation of the color orientation map of the surface of a grain (b) specimen with a strong reorientation of the wide strip that crosses all the grain. Experimental procedure [6] allowed us to estimate the time of its development. Its development time does not exceed a few seconds. At this rate of development, apparently does not have time to occur relaxation stress state in the grain, resulting in a jump of the deforming stress.

\subsection{Substructure, orientation heterogene-} ity and cracks

As already mentioned above, substructural and orientation changes accompanying the plastic deformation of polycrystalline specimens, are quite diverse. Within one and the same polycrystalline specimen in the grains constituting it may be different in character and patterns of orientation and substructural changes. In particular, there may substructural and orientational changes ultimately lead to the emergence of cracks in the grain. Below is one example of the emergence and development of cracks as a result of the preceding substructure and orientation changes (Fig. 8).

One of subgrain boundaries (in Fig. 8a is indicated by an arrow) to a deformation of the specimen is the meandering. During the deformation of the specimen the boundary is aligned (Fig. 8b) and moves to the edge of the specimen (Fig. 8c). Moving the boundary accompanied by an increase in the misorientation subgrain on the boundary $\Delta n$ (Fig. 9). In the area of intersection of

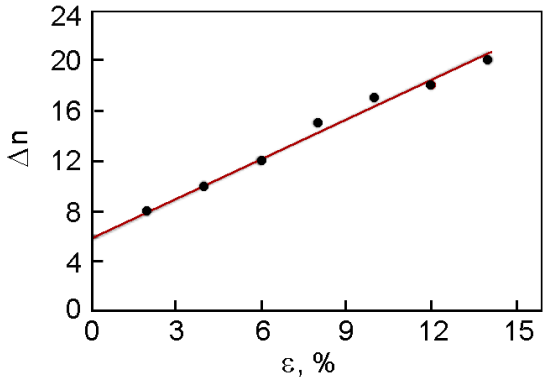

Fig. 9. Misorientation changing on the subgrain boundary during deformation of an $\mathrm{Al}$ specimen.

the boundary of the specimen with its edge occurs crack (Fig. 8d), the development of which takes place along the grain boundary.

Fig. 10 illustrate another example of the orientation changes and substructural preceding occurrence cracks in the specimen. It is shown at color orientation maps derived from the region of the $\mathrm{Al}$ polycrystalline specimen containing five grains, in situ during the deformation.

Determination of the crystallographic orientation of the five grains and attestation of all the grain boundaries showed that of the seven grain boundaries of the four boundaries, taking into account the criterion of Brandon, close to special grain boundaries. This boundary is "1-2", "2-3", " $3-4$ " and "4-5". The boundaries of "1-5", "1-3" were boundaries of the general type, and the boundary of "3-5" is small-angle boundary.

Characteristic for this area of the specimen is discovered during deformation the effect of a dispersal of two grain boundaries - small-angle boundary "3-5" and general boundary "1-3". Dispersal of first grain boundary accompanied by decreases of angle misorientation of the grain, and this decrease is mainly due to the change in crystallographic orientation of the grain 3 . On the color orientation map obtained from the 


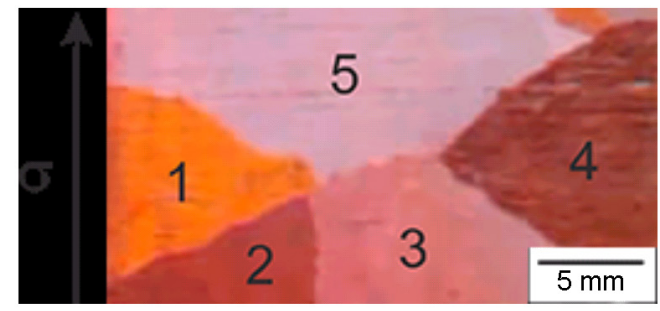

a)

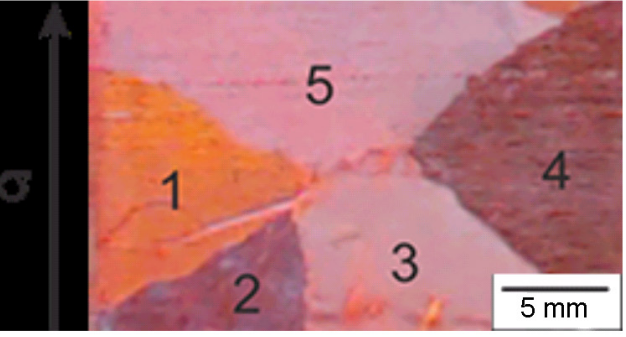

b)

Fig. 10. Color orientation maps of an Al specimen fragment before deformation (a) and after deformation by $27 \%$ (b).

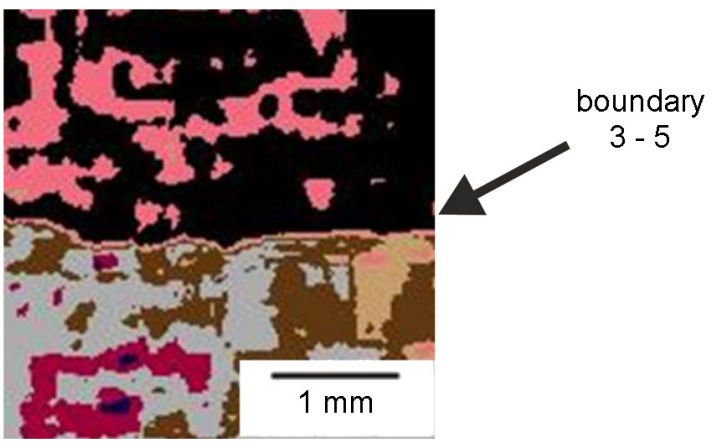

a)

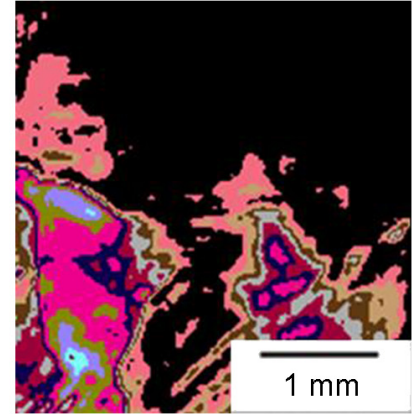

b)

Fig. 11. Color orientation maps of the boundary region of two grains 3 and 5 of an Al polycrystalline specimen after visualization of the effect of a dispersal of grain boundaries: $a-\varepsilon=0 \%$; $\varepsilon=27 \%$.

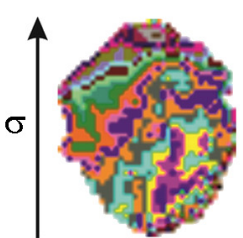

a)

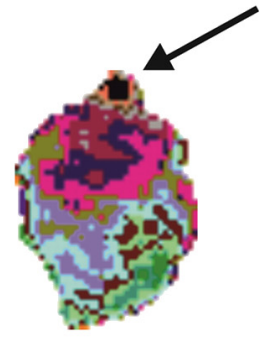

b)

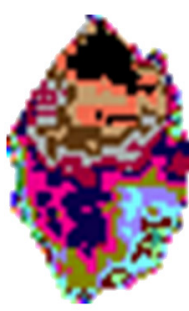

c)

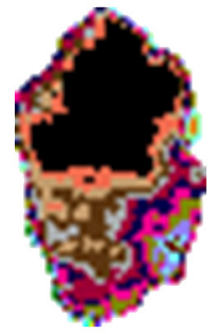

d)

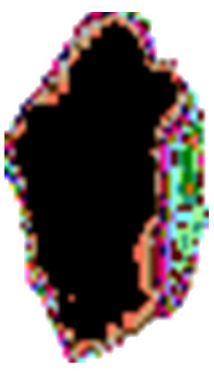

e)

Fig. 12. Color orientation maps of one of the grains of an Al polycrystalline specimen after substructure and orientation heterogeneity visualization: $\mathrm{a}-\varepsilon=0 \% ; \mathrm{b}-\varepsilon=8 \% ; \mathrm{c}-\varepsilon=$ $15 \% ; \mathrm{d}-\varepsilon=18 \%$; e $-\varepsilon=25 \%$.

specimen surface after its deformation, the color hues of the image surface of the two grains are practically indistinguishable. This is confirmed by the Laue diffraction patterns derived of the grains after the destruction of the specimen. Cause of a dispersal of grain boundary "1-3", apparently is a substantial increase in length of the boundary "1-3" more than 4 times, resulting in the occurrence decompaction and crack in this grain boundary. Crack growth occurs in the body of the grain 1 Effect of a dispersal of grain boundary " $3-5$ " when the deformation of the specimen was $27 \%$ well is illustrated in Fig. 11. In Fig. 11 shows the results of visualization of subgrain structure near the boundary.

As already mentioned above, one of the features of plastic deformation of polycrystalline specimens is its local heterogeneity. It was shown experimentally that the local relative plastic deformation of individual grains of two-dimensional Al polycrystals can significantly exceed the relative deformation of the entire specimen. This deformation is usually accompanied by a marked reversal of grain. Fig. 12 shows a fragment of color orientation maps of the surface of 
one of grains of Al specimen derived in situ during the deformation. The relative deformation of that grain by the time of destruction of the specimen is almost twice above the relative deformation of the entire specimen. Appreciable orientation change of grain as a whole show the pattern of Laue diffraction obtained from the surface of the grain before and after deformation of the specimen. Shown in Fig. 12 COM allow to determine the mechanism that changes the orientation of grains and explain its abnormally high relative plastic deformation.

The Fig. 12 show forming substructure of the grain during deformation of the specimen. When the strain $\varepsilon \approx 8 \%$ on top of the grain (on the picture) is formed region with grain orientation different from the orientation of all other areas of grain. With further deformation of the specimen, the area of region increases. When the deformation of the specimen was $\varepsilon \approx 25 \%$ this area of the grain is $\approx 85 \%$ of the surface area of all grains. Results of changing the width of the spectrum of misorientations subgrains $(\Delta n)$ in grain, depending on the relative deformation are presented on Fig. 13. Over the entire period of deformation, the value of $\Delta n$ decreases by more than 5 times. It should be noted, that with such substructure and orientation changes in grains during the deformation of the specimen achieved the highest level of relative deformation.

For the given in Fig. 12 grain critical relative deformation is more than $40 \%$ (for the specimen it is $25 \%$ ). And, the last, fine blocks structure $(1-5 \mu \mathrm{m})$ with a wide spectrum of misorientations which changed during deformation of the grain was found near the boundaries of grains with abnormally high relative deformation. Whose spectrum of misorientation changed during deformation. Apparently, the presence of such a structure near grain boundaries played an accommodative role and excluded the possibility of discontinuities in grain and grain boundaries during deformation of the specimen.

\section{Conclusions}

Systematic studies of the substructure and orientation changes occurring in different grains of polycrystalline aluminum specimens with a parquet structure in situ during the deformation of the specimen were carried out. It is shown that the main mechanism of these changes has been the

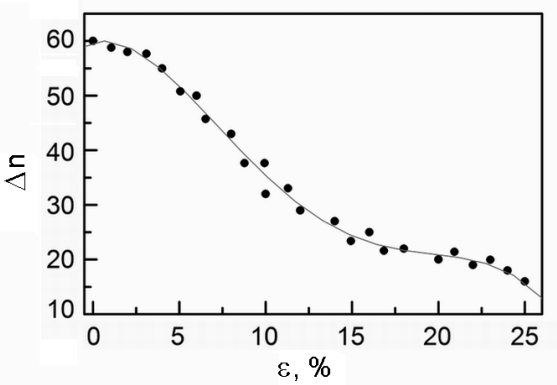

Fig. 13. Changing spectrum of misorientation of subgrain structure of the grain during deformation of the specimen.

fragmentation of the subgrain structure with a wide spectrum of misorientations.

It is shown in experiment that a new observed effect of a dispersal of small-angle and general grain boundaries during plastic deformation was typical for researched specimens. Subgrain and orientation restructuring took place near the boundaries of the first type during plastic deformation. It led to a change in crystallographic orientation of the grains. In the second case, there was an abnormally high relative deformation of the region which contained the grain boundary. It leads to decompaction of the grain boundary and the emergence of crack in its area.

For a small part of all the investigated grains the relative deformation of the grain which was significantly higher than the relative deformation of the entire specimen has been observed. The deformation of such grains is accompanied by a noticeable change in their crystallographic orientation. Color orientation maps which obtained from the surface of these grains during the plastic deformation of the specimen allowed to determine the mechanism of plastic deformation and orientation changes in the grain. It was in a specific and consistent orientational restructuring of the subgrain structure within grain. Fine block structure $(\bar{d}<5 \mu \mathrm{m})$ with a wide spectrum of misorientations which changed during deformation of the grain was found near the grain boundaries. The presence of such structure near grain boundaries played an accommodative role and excluded the possibility of discontinuities in grain and grain boundaries during deformation of the specimen.

\section{References}

1. E.E.Badiyan, A.G.Tonkopryad, O.V.Shehovtsov et al., Zavodskaya Laboratoriya, Diagnostika Materialov, 76, 34 (2010). 
2. E.E.Badiyan, A.G.Tonkopryad, O.V.Shehovtsov et al., Inorganic Materials, 15, 1663 (2011).

3. Patent Ukraine 89743 (2010).

4. Patent Ukraine 104249 (2014).

5. E.E.Badiyan, A.G.Tonkopryad, O.V.Shekhovtsov et al., Functional Materials, 21, 307 (2014).

6. E.E.Badiyan, A.G.Tonkopryad, O.V.Shehovtsov et al., Zavodskaya Laboratoriya, Diagnostika Materialov, 80, 37 (2014).
7. M.Beckert, Ch.Klemm, Spravochnik po Metallograficheskomu Travleniju, Metallurgia, Moscow (1980) [in Russian].

8. N.A.Koneva, E.V.Kozlov, Vestnik TGU, 8, 514, Tomsk (2003).

9. N.A.Koneva, E.V.Kozlov, Fizika, 33, 89 (1990).

10. G.A.Malyigin, Uspekhi Fiz. Nauk, 9, 979 (1999). 